\title{
The role of cuspate spits on wave attenuation and energy redistribution in a coastal lagoon, Lagoa dos Patos, Brazil.
}

Inaiê Malheiros Miranda ${ }^{\mathrm{a}, \mathrm{c}^{*}}$, Elírio Ernestino Toldo Jr. ${ }^{\mathrm{a}, \mathrm{b}^{*}}$, Antonio Henrique da Fontoura Klein $^{\mathrm{c}}$, Darrell Strauss ${ }^{\mathrm{d}}$, Guilherme Vieira da Silva ${ }^{\mathrm{d}}$

a Programa de Pós-graduação em Geociências, Universidade Federal do Rio Grande do Sul (UFRGS), Campus do Vale - Agronomia, Porto Alegre, RS - 91501-970, Brazil.

${ }^{\mathrm{b}}$ Centro de Estudos de Geologia Costeira e Oceânica, Instituto de Geociências, Universidade Federal do Rio Grande do Sul (UFRGS), Campus do Vale - Agronomia, Porto Alegre, RS - 91501-970, Brazil.

${ }^{\mathrm{c}}$ Laboratório De Oceanografia Costeira, Coordenadoria Especial de Oceanografia (OCN), Centro de Ciências Físicas e Matemáticas (CFM), Universidade Federal de Santa Catarina (UFSC), Campus Universitário - Trindade, Florianópolis, SC - 88040900, Brazil.

${ }^{\mathrm{d}}$ Griffith Centre for Coastal Management, Room 2.01, Building G51, Griffith University, Gold Coast Campus, Queensland - 4222, Australia.

Corresponding author: miranda.inaie@gmail.com. 


\begin{abstract}
This research uses a process-based model (Delft3D), validated with measured wave data, to investigate the controls that a cuspate shoreline and its associated submerged morphology have on wave generation, propagation and attenuation within a large elongated lagoon (Lagoa dos Patos, Brazil). A method based on the Energy-FluxMethod was applied to the historical wind dataset to define representative wind cases to be used as forcing conditions in the model. The results show that, during extreme wind conditions, the spits dissipate wave energy in the lagoon. This (wave attenuation and the wave sheltering effect) controls the stability of the adjacent coastline. The wave attenuation varies between 18 and $46 \%$ along the submerged spit depending on the crest width and the amplitude of the incident waves. Waves are mainly attenuated in the proximal and central portions of the spits where the spits are wider, resulting in a reduced transmitted energy to the adjacent coastline, while larger waves are also attenuated on the distal end of the spits. The degree of attenuation depends on the direction of wave generation, the respective fetch, the spit width, and the water depth. A strong relationship of mutual co-adjustment between the morphology and the wave field results in a very low occurance of oblique wave angles of incidence, especially for waves propagating accross the long lagoon axis. Furthermore, the wave attenuation over the spits is also responsible for its progressive erosion, which from decades to centuries, may lead to an increase of changes on the lagoon shorelines.
\end{abstract}

Keywords: Delft 3D, wave dissipation, wave energy gradients, wave propagation, wave shadow, cuspate shorelines, fetch-limited.

\title{
Introduction
}

Understanding changes in the wave characteristics of the nearshore zone is an issue of fundamental importance because it drives sediment transport that will produce 
morphological changes, which in turn alters the fluid dynamics, restarting the cycle which drives the coastal evolution (Cowell and Thom 1994).

The temporal behavior of the coastal systems varies according to the directionality of the wave climate, which can vary globally because of changes in the wind climate induced by climate change, or locally, because of changes in the wave transformation processes controlled by the nearshore bathymetry (López-Ruiz et al. 2014; López-Ruiz et al. 2015). Therefore, a better understanding of coastal processes in the nearshore zone can increase our capacity to predict coastal changes at different time scales, increasing the potential to assist in the enhancement of coastal community resilience and the management of natural resources.

Researchers and coastal managers have shown an increased interest in predicting the shoreline behavior at larger time and spatial scales (Ells and Murray 2012; Nicholls et al. 2013). However, there is still a demand for improved prediction of change which occurs locally (French et al. 2016) to better inform the decision making of coastal planning and/or protection measures. In this sense, this research has the main focus of better understanding local processes occurring along the central west margin of Lagoa dos Patos (Brazil), where a touristic beach is located (Arambaré) (Fig. 1).

The lagoon settings constitute a good opportunity to investigate the wave dynamics in a fetch-limited complex coastal system. The studied region is a typically elongated lagoon, with very large dimensions $\left(>10.000 \mathrm{~km}^{2}\right)$ constricted into four main "cells" by three large-scale cuspate spits extending underwater below $1 \mathrm{~m}$ depth until approximately the center axis of the lagoon. High energy wind-waves can be generated in the lagoon, wherein a maximum of $1.6 \mathrm{~m}$ and $4.8 \mathrm{~s}$ of wave height and period was predicted by Toldo et al. (2003) under a windstorm of $25 \mathrm{~m} / \mathrm{s}$ from the WNW direction.

The coastal morphology of lagoons resemble the coastal morphology of the ocean shore as many processes found on lakes and lagoon shores are similar to those found on the ocean shore (Carter 1988). Physical features become more comparable with increasing dimensions of the water body and smaller tidal range (Aronow 1982). In this sense, this work investigates the controls of the lagoon cuspate shoreline (orientation) and the associated submerged morphology (in particular the submerged cuspate spits and the morphological transition zone of the shoreface width) on the alongshore distribution of the incident wave characteristics, including the analysis of different directions of waves generated by representative wind cases, propagation patterns and the wave attenuation by the spits. 
Significant advances were achieved in the understanding of the wave input forcing on the large-scale coastal behavior of cuspate shorelines (Ashton and Murray 2006a; Ashton and Murray 2006b). However, the influence of nearshore processes, such as the modification of incident wave directions is not well understood (Thornton et al. 2000), especially in coastal environments dominated by locally generated, fetch-limited, young seas.

Spits are among the most dynamic coastal landforms on the Earth Surface, whose development is primarily controlled by the sediment supply (Héquette and Ruz 1991; Park and Wells 2007), and by the characteristics of the incident wave conditions. Cuspate spits are a type of spit that develops within fetch-limited water bodies (ex.: elongated lagoons or marginal seas), in which fetch-limiting controls result in a prevailing occurrence of oblique wave-approach angles at the beginning of the rectilinear shore (Zenkovitch 1959; Rosen 1979; Toldo 1991; Toldo et al. 2003).

A rectilinear shore composed by unconsolidated sediments is an unstable shape under a dominant oblique wave incidence to the shore. As a result, the shoreline is reoriented in accordance to the dominant wave-approach directions due to strong gradients on the longshore sediment transport, which leads to the formation of cuspate shoreline features (Zenkovitch 1959; Rosen 1979; Ashton et al. 2001). Finally, when those features reach a finite-amplitude, they start to interact with each other by the wave-sheltering effect, resulting in the self-organization of the coast driven by strong feedbacks between the longshore sediment transport and the morphology (Ashton et al. 2001; Ashton and Murray 2006a, b).

A long-term requirement for a fetch-limited environment to achieve an equilibrium shape is that energy needs to be efficiently spread along the shore (Carter, 1993). By absorbing and adjusting to environmental changes, the shoreline increases its potential to become a buffer against fluctuations in ambient energy, especially during storm events (Carter and Woodrofe 1994). In the case of an elongated lagoon composed by unconsolidated material, paired cuspate spits develop (Zenkovicth 1959; Rosen 1979; Carter 1993).

Spits are recognized by their importance in providing natural coastal protection from the direct wave attack to nearby beaches (FitzGerald and Buynevich 2009; Allard et al. 2008). Cuspate spits, in particular, have a far-field response in the stabilization of its leeward coast due to the wave sheltering effect (Ells and Murray 2012) which controls the sediment transport patterns and thus erosion-prone areas. Moreover, this work 
demonstrates the buffering effect of the emerged and submerged cuspate spits during high wave energy events in the lagoon.

Several studies have reported on the relationship between the spits and the wave regime (Ashton and Murray 2006b; Park and Wells 2007; Allard et al. 2008; LópezRuiz et al. 2012; Escudero et al. 2019). Ashton and Murray (2006b) have shown how the angular distribution of the incident waves affects the long-term development of cuspate spits, as; 1 ) the major proportion of anti-diffusive waves (oblique wave incidence below the toe of the shoreface) increases the amplitude growth of the cuspate features, and that 2) the degree of asymmetry of the wave regime are preponderant parameters for the shape and forms of evolution of the cuspate features. Allard et al. (2008) showed that variations in sand accumulation on spits, at seasonal to interannual time-scales, are the result of variations in the longshore sediment transport modulated mainly by wave height. Petersen et al. (2008) has found that the radius of curvature of spits varies according to the height of the incoming waves. A López-Ruiz et al. (2012) study on a schematic "flying spit" showed that different combinations of significant wave height, period and angle of incidence (the determinant parameter) produces different surfzone widths. Thus, evidencing the high control in the alongshore distribution of incident wave angles and heights on the morphodynamics of coasts with spits.

In this sense, this research assesses the influence of spits on the wave height attenuation and on the incident wave characteristics [energy $(\mathrm{W} / \mathrm{m})$ and angle of incidence $(\varphi-\theta)$ ] entering the nearshore region of the lagoon bay beaches, considering different directions of wind-wave generation. Despite wave attenuation studies receiving more attention by the scientific community since the 1990's, with an increased number of published studies since 2012 (Scopus searching for "wave attenuation" and refined to "swell" and "wind-wave") in different types of environments, this is the first time that the impact of spits on wave attenuation within a lagoon water body has been assessed. In this context, this work is guided by the following research questions:

1. To what degree do the large-scale cuspate submerged features act on the wave attenuation, considering extreme wave fields from different directions in the fetch-limited water body of Lagoa dos Patos, Brazil?

2. How does the control of the coastline orientation and submerged relief of the lagoon margin (where the cuspate spits constitute the most important features) 
act on the incident wave characteristics in the nearshore region of the associated lagoon beaches?

This paper first contextualizes the analyzed lagoon system and the local environmental conditions in the regional setting section, followed by the methodology steps for the selection of representative wind cases used as forcing conditions for the lagoon wave model. The model calibration and validation procedures, and the measurements of the alongshore wave energy and attenuation were then described. Next, the wave attenuation by the spits and the alongshore distribution of the wave energy and angles of incidence are presented in the results section. The results are followed by a discussion on the controls of the variability of wave attenuation along the spits and the implication for the adjacent coastline, the alongshore distribution of wave-approach angles $(\varphi-\theta)$ and energy $(\mathrm{W} / \mathrm{m})$ in the nearshore region of a cuspate coast in its final stages of development. Finally, we present the main conclusions of the research.

\section{Regional Setting}

The coastal plain of Rio Grande do Sul is composed by four barrier-lagoon systems, formed during four transgressive-regressive events associated with four sea-level highstands, where the Patos-Mirim Lagoon Complex is the dominant feature (Tomazelli et al. 2000).

The regional climate (see Fig. 1 for location) is marked by the influence of the Atlantic anticyclonic wind circulation which leads to the dominant northeasterly $\left(5 \mathrm{~m} \mathrm{~s}^{-}\right.$

${ }^{1}$ mean velocity) wind action throughout the year, followed by southwesterly and southerly winds ( $8 \mathrm{~m} \mathrm{~s}^{-1}$ mean velocity) during the passage of cold fronts, most frequent during winter and autumn (Delaney 1965; Stech and Lorenzetti 1992; Tomazelli 1993; Klein 2012). It has a total mean annual precipitation of 1200-15000 mm, which may strongly vary from year to year and is principally related to the path and frequency of cold front passages (Nobre et al. 1986).

Strong El Niño phases were also correlated with an increased precipitation pattern over the drainage basin of the state (Schooler et al. 2018), resulting in an increase of the discharge of the main lagoon tributary - Guaíba river (Vaz et al. 2006). The resultant increase in the lagoon water level (Fernandez et al. 2002) allied to an increased frequency of cold front passages (Saraiva et al. 2003) resulted in an increased shoreline 
retraction over the study area within a short-time period, from 1997-1999, in spite of the medium-term tendency coastal stability(Miranda et al. 2019).

\section{Local Wind Climate}

The analysis of the wind dataset is in accordance to previous studies of the wind regime of the region (Klein 2012). Where, higher occurrence of winds from the NE direction are observed, with magnitudes between 5.5 and $8.0 \mathrm{~m} / \mathrm{s}$, classified as a moderate breeze (Beaufort 5) (Table 1). Furthermore, there is a considerable occurrence of wind speeds ranging from 8.0 to $10.8 \mathrm{~m} / \mathrm{s}(12.4 \%)$ corresponding to Beaufort 6 . Wind from the NE direction dominates the frequency of occurrence (14.1\%), followed by the ENE (10.2\%), E (7.6\%), S (6.8) and SSW (6.2\%) directions. Wind speeds between 10.8 to $13.9 \mathrm{~m} / \mathrm{s}$ occur mainly from the NE, S and SSW directions and near gale cases (Beaufort 8) occur mainly from the S, followed by the E and ESE, NE and SSW directions.

Table 1. Joint occurrence of wind speed $(\mathrm{m} / \mathrm{s})$ and directions with the number of hours per class. The darker shades of gray indicate classes with higher frequency of occurrence.

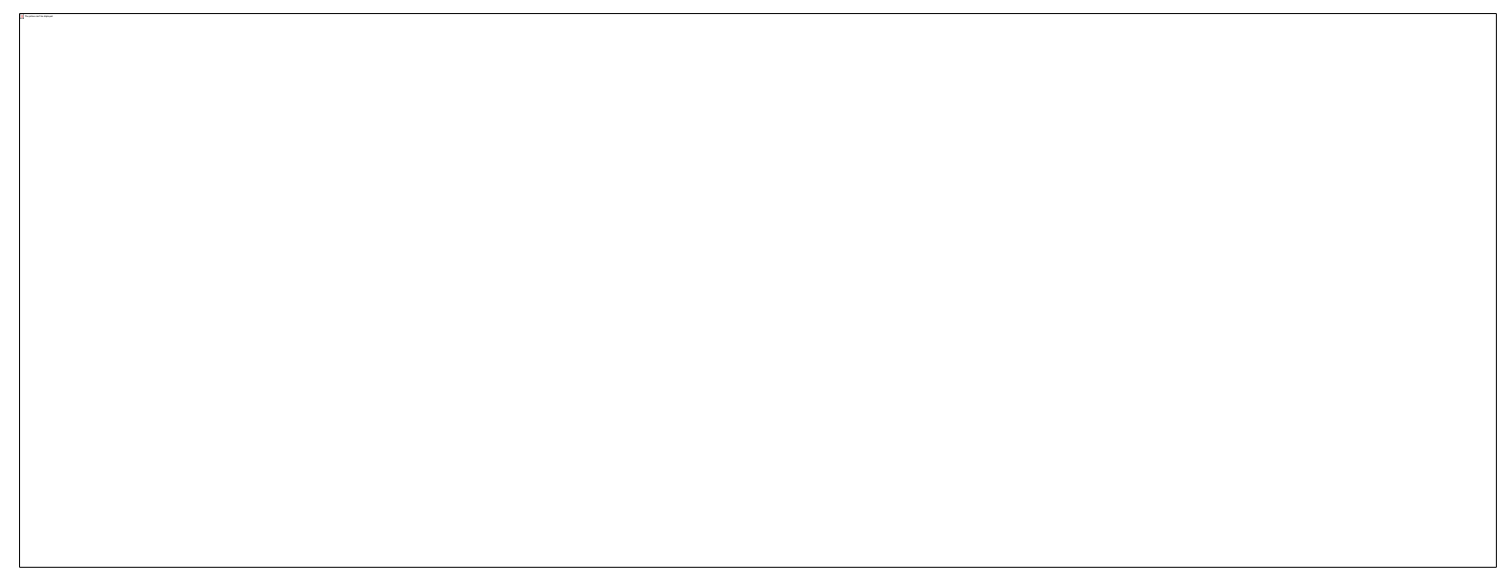

\section{Lagoa dos Patos}

The lagoon water body covers a surface area of approximately $10,000 \mathrm{~km}^{2}$ (Toldo et al. 2006b), it is $240 \mathrm{~km}$ long, the largest width reaches $59.8 \mathrm{~km}$, and it has an average depth of $6 \mathrm{~m}$ (Toldo 1991). 
A succession of broad bays and sandy spits occur on the lagoon margins as a result of the wave action and related littoral currents which tend to orient the beaches at right angles to the direction of the prevailing waves (Delaney 1965; Villwock 1984; Toldo et al. 2003). Despite the wave power being inferior when compared to an open ocean beach, the lagoon shoreface is considered an energetic environment for a lagoon, with an annual mean wave-power incident on the west margin of 2,057 kW/m-1 and 1,046 $\mathrm{kW} / \mathrm{m}-1$ on the east margin, and despite the east side receiving less energy than the west side, the storm condition is typical for the east side (Toldo et al. 2003).

The lagoon beaches associated with the spits fulfill the definition of bay beaches proposed by Nordstrom (2005), in which locally generated waves and wave-induced currents are the main factors affecting the bay beach morphodynamics. This is despite wind-induced and tidal currents which may also play a role in morphological changes. For the case of Lagoa dos Patos, the inlet acts as a dynamic low-pass filter that eliminates tidal and subtidal effects inside the lagoon water body (Moller et al. 1996; Fernandes et al. 2004).

Also, the two main longitudinal components of the winds exert an important control on the set-up/set-down oscillation mechanism, for instance, during low discharge, the $\mathrm{NE}$ wind cause a decrease in the lagoon water level on the north region and an increase in the south, facilitating the leak-flow towards the sea, as opposed the the SW wind, while the central lagoon water body constitutes the nodal zone (Moller et al. 1996).

Based on 21 years of measured data, from 1985 to 2006, Andrade Neto et al. (2012) found an average discharge value from the main contributor of the Guaiba river to be $988 \mathrm{~m}^{3} /$ year, with a maximum discharge of $5,246 \mathrm{~m}^{3} / \mathrm{s}$.

The west lagoon margin is marked by the presence of six lagoon sandy spits (Toldo 1991), among which, the three symmetrical rhythmic features on the central landward margin, and the associated northern (Arambaré) and southern bay beaches, are the focus of this research (Fig. 1). Table 2 depicts the details of the morphological characteristics of the analyzed spits.

In addition, Miranda et al. (2019) indicated that the west lagoon spits are experiencing a phase of limited sediment supply, such that no representative shoreline recession rates were found along the lagoon bay beaches (the source of sediments to the spits) in the medium-term assessment of shoreline changes; i.e. the shorelines showed an average change rate of $\pm 0.7 \mathrm{~m} \mathrm{y}^{-1}$ (within the uncertainty error). In an inter-annual period, in turn, the bay beaches showed alternateing phases of stability, deposition, and 
recession (albeit less frequent) trends (Miranda et al. 2019). The authors also highlighted the need for studies regarding the frequency and direction of storm wind conditions and the resultant wave regime and sediment transport patterns along the lagoon coast to better understand and predict possible morphological changes.

Figure 1. Study area, with the distribution of control points along the submerged spits to the wave attenuation measurements (triangles), and along the lagoon bay beaches to the alongshore distribution of the wave energy (circles). Locations of the wave buoy (Directional Waverider MkIII) moored at $\sim 6 \mathrm{~m}$ depth, and the wind recording station (Mostardas/ INMET). Directional wave roses of Hs at deeper waters in the center of each lagoon cell for the year of 2015 .

Table 2. Parameters of the submerged lagoon sandy spits ('cuspate spits') based on the Bathymetric Brazilian Chart. (*W.r.t. $\mathrm{N}=$ with respect to the north)
Cuspate Spits
Proximal point
Centre
Distal point
Orientation

Width $(\mathrm{km}) \quad$ Width $(\mathrm{km}) \quad$ Width $(\mathrm{km}) \quad$ W.r.t. $\quad$ Facing Facing 


\begin{tabular}{lccccccccc}
\hline Isodepth & $\sim 1 \mathrm{~m}$ & $\sim 3 \mathrm{~m}$ & $\sim 1 \mathrm{~m}$ & $\sim 3 \mathrm{~m}$ & $\sim 1 \mathrm{~m}$ & $\sim 3 \mathrm{~m}$ & $\mathrm{~N}$ & $\mathrm{NE}$ & $\mathrm{SW}$ \\
\cline { 1 - 4 } Dona Helena & 2.28 & 3.38 & 1.10 & 2.62 & 0.21 & 1.32 & $129.5^{\circ}$ & $39.5^{\circ}$ & $219.5^{\circ}$ \\
Dona Maria & 3.85 & 7.45 & 1.54 & 4.17 & 1.55 & 2.78 & $133.0^{\circ}$ & $43.0^{\circ}$ & $233.0^{\circ}$ \\
Vitoriano & 3.61 & 7.05 & 0.45 & 2.60 & 0.27 & 1.43 & $135.4^{\circ}$ & $45.5^{\circ}$ & $225.4^{\circ}$
\end{tabular}

\section{Material and Methods}

The flowchart below (Fig. 2) presents the methodology steps of this study and is further explained in the following sections.

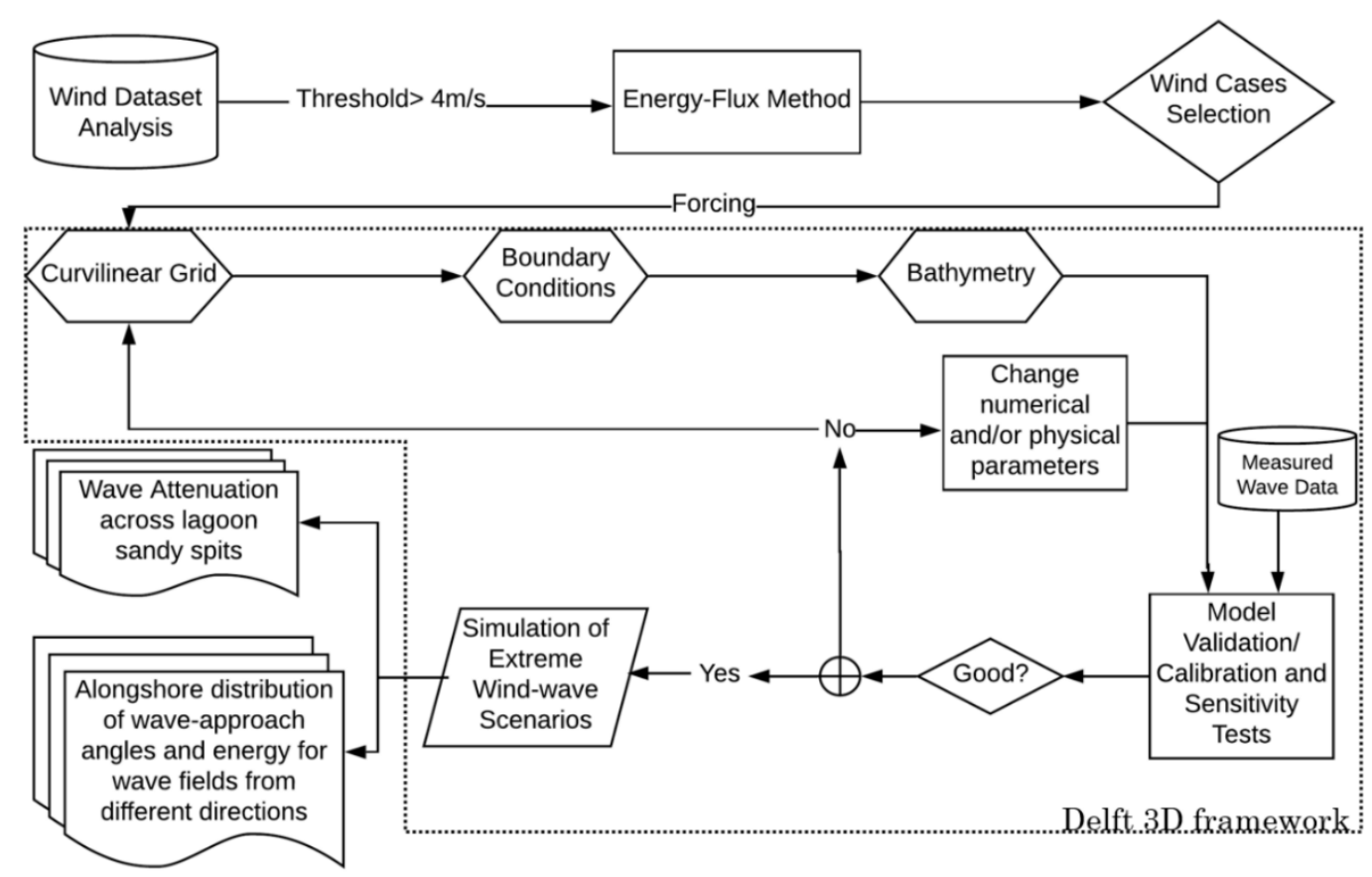

Figure 2. Flowchart illustrating the methodology steps.

The waves in the lagoon are solely generated by wind forcing. Therefore, the wind dataset was first analyzed in order to identify representative wind conditions over the region (Table 1), followed by the selection of wind cases as further detailed.

Wind Case Selection. 
Local hourly wind data from 2008 to 2016, collected from Mostardas weather station (INMET Brazil), 31 ${ }^{\circ} 14^{\prime} 53.8^{\prime \prime} \mathrm{S}$ and $50^{\circ} 54^{\prime} 22.6^{\prime \prime} \mathrm{W}$ (Fig. 1), was first analyzed using the joint distribution function (see Table 1). Then, simulation tests using wind speeds below $4 \mathrm{~m} / \mathrm{s}$ for the 16 directions $\left(\mathrm{N}-\mathrm{NNO}, \Delta \theta=22.5^{\circ}\right)$ showed that below this threshold, the winds do not generate waves capable of inducing sediment transport. Therefore, wind speeds below $4 \mathrm{~m} / \mathrm{s}$ from all directions were filtered out, and a method similar to the Energy-Flux-Method (EFM) (Benedet et al. 2016) was applied in the remaining wind dataset (accounting $64.56 \%$ of the total time period). The EFM is an input reduction method to determine representative cases (of different magnitudes and directions) from a time series. The classes with the highest magnitude ( $>9 \mathrm{~m} / \mathrm{s})$ were used as forcing conditions (Fig 3).

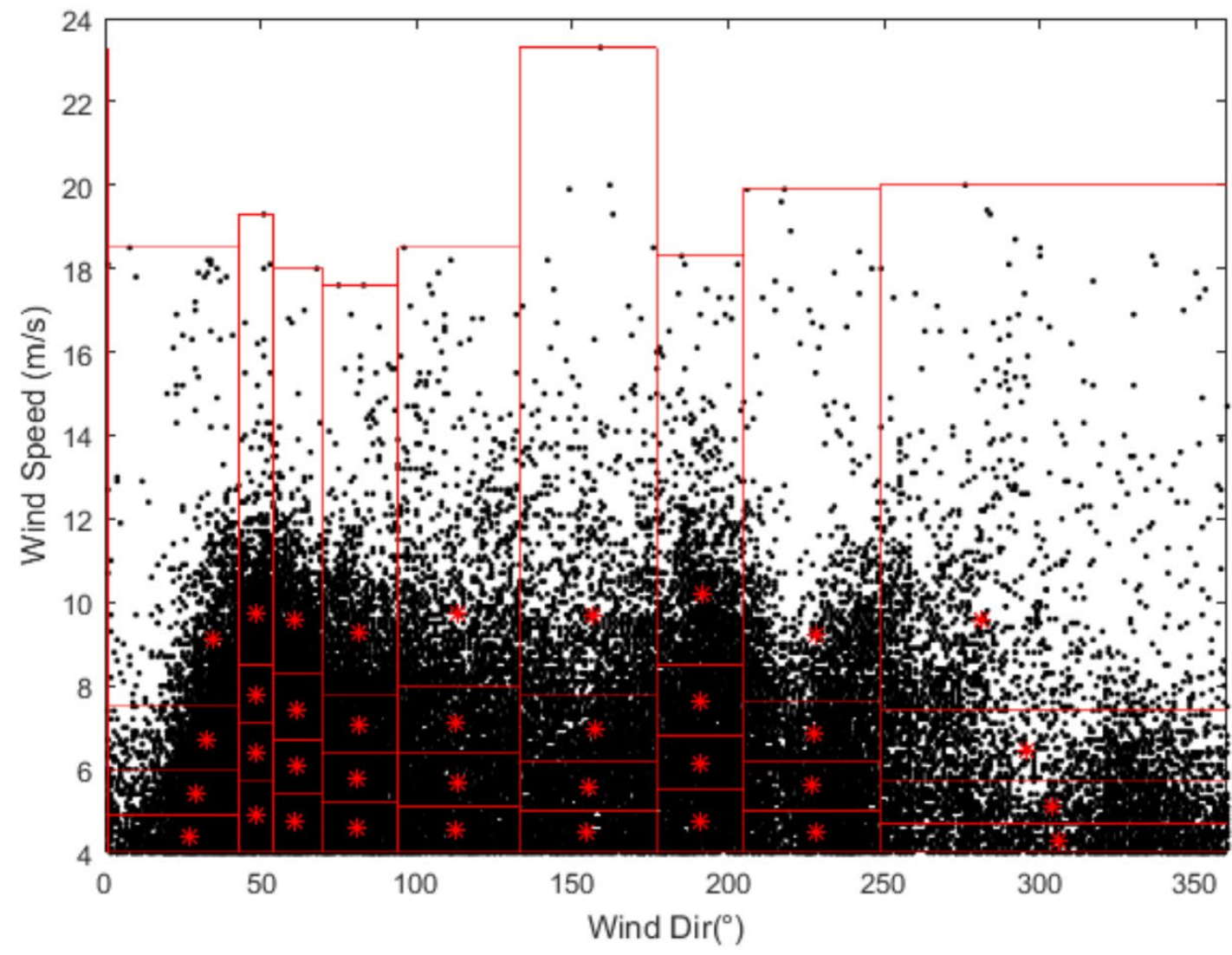

Figure 3. Representation of the discretization of the remaining wind dataset into 36 representative wind cases (red dots).

Wind-wave modelling

The third generation wave model SWAN (Simulating Waves Nearshore) was used to simulate realistic wind-generated wave conditions within the lagoon water body, through the Wave module, from the Delft3D framework (developed by Deltares in co- 
operation with the Delft University of Technology), in an online coupled mode with the Flow module (Lesser et al. 2004; Roelvink 2006), in order to account for the effects of waves on flow and vice-versa. The hydrodynamic conditions (e.g.: velocities, water elevation) calculated in the Delft3D-FLOW module are used as input to the Delft3DWAVE module (SWAN) and vice-versa through a so-called communication file. SWAN is a fully spectral (in all frequencies and directions) third-generation wave model based on the Eulerian formulation of the discrete spectral balance of action density (Booij et al. 1999; Ris et al. 1999). Further information on the numeric formulations of all relevant physical processes computed in SWAN and used in this research (wave generation by wind - linear and exponential wind growth, (refraction) propagation due to current and depth variations, non-linear triad wave-wave interactions, and wave energy dissipation by whitecapping, bottom friction and depthinduced wave breaking) can be found in Booij et al. (1999) and Ris et al. (1999).

A curvilinear grid containing 762 and 198 grid cells in the y-and x-directions was used for the Lagoon model. A coarser grid resolution was set outside the interested area, smoothly varying from $200 \mathrm{~m}$ up to $600 \mathrm{~m}$, and locally refined in the area of interest $(98-200 \mathrm{~m})$ to ensure a good representation of the lagoon margins and the spits' morphology (Fig. 4a).

The model domain covers almost the entire water body, disregarding the initial $9 \mathrm{~km}$ of the lagoon inlet (less than $4 \%$ of the Lagoon length) due to the lack of reliable data to provide boundary conditions. The tidal and sub-tidal signals are filtered out inside the Patos Lagoon and the wind influence on water levels is significantly greater (Moller et al. 1996 and Fernandes et al. 2004). Therefore, for this study, offshore tidal variations were not propagated towards the lagoon. The average discharge of the Guaíba river ( 988 $\mathrm{m}^{3} /$ year) based on Andrade Neto et al. (2012) was also used as a boundary condition. At the extreme south (outlet) an open water level boundary with astronomic forcing was used with data provided by Praticagem Rio Grande (Brazil).

The bathymetry data is based on the Brazilian Navy Nautical Chart number 2140 and nine bathymetric profiles from the same source. The Navy Chart presents a scale of 1:270,000 of a survey conducted in 1964. The depth samples were adjusted based on the reduction level measured at Arambaré and São Lourenço Station $(0.33 \mathrm{~m})$, and the bathymetric data were interpolated using the grid cell averaging technique in areas with sufficient depth samples, giving special attention to the study area and, where the depth samples were scarce, the triangular interpolation method was applied (Fig. 4b). The 
calibration of the model and the general trends observed are good indications that the bathymetric data, despite not being recent, are a good representation of the study area for scientific research purposes.

Figure 4. a) Curvilinear grid with the north and south boundaries highlighted by the dashed circles and, the interest area situated inside the dashed square; b) bathymetry of the lagoon water body.

Model Calibration/Validation and Sensitivity Tests

A series of model tests were simulated with the lagoon model for one month, from $01 / 30 / 2015$ to $03 / 03 / 2015$, to test the sensitivity of the physical parameters and to calibrate the model. Also, a longer time-period was considered for the model validation, from February to April, 2015, a time period that co-incided with measured in-situ data when the Waverider Datawell Mark III was deployed (see Fig. 1 for location).

The following numerical settings and formulations of the physical processes were tested: 1) The bottom dissipation formulation of Madsen et al. (1988) was selected, with the physical roughness of $0.05 \mathrm{~m}$ following the value used in Chesapeake Bay by Lin et al. (2002) - and the empirical JONSWAP formulation of Hasselman et al. (1973), i.e. testing bottom friction coefficients $\left(\mathrm{C}_{b}\right)$ with the value $0.038 \mathrm{~m}^{2} \mathrm{~s}^{-3}$ recommended for swell conditions (Hasselmann et al. 1973) and $0.067 \mathrm{~m}^{2} \mathrm{~s}^{-3}$ for wind sea conditions (Bouws and Komen 1983); 2) the whitecapping mechanism, by (de)activation of the process and by comparing the adapted form of Komen et al. (1984), and the revised source term of Westhuijsen et al. (2007) and; 3) the wave-wave non-linear triad interactions (ANEXX -A). 
The model results were checked against measured data and the quality was measured by the following statistic metrics: Root-mean-square error (RMSE) (1), symmetrical slope (sym r) (2), and bias parameter (BIAS) (3). Where $P_{i}$ is the predicted variable and $O_{i}$ is the measured variable, $N$ is the number of data, as follows:

$$
\begin{gathered}
R M S E=\sqrt{\frac{1}{n} \sum_{i=1}^{n}\left(P_{i}-O_{i}\right)^{2}} \\
\text { sym } r=\sqrt{\frac{\sum P_{i}^{2}}{\sum O_{i}^{2}}} \\
\text { BIAS }=\frac{1}{N} \sum_{i=1}^{N}\left(P_{i}-O_{i}\right)
\end{gathered}
$$

The model outputs of significant wave height (Hs), peak wave period (Tp), U and V current speed components converted from the magnitude and direction were considered for the model validation. The representative model run tests with their results are included in the supplementary material (Annex-A, Annex-B).

\section{Model set-up}

The physical and numerical settings which conferred a good agreement between the modelled and measured wave parameters (Fig. 5), based on the results of the previous runs, are further detailed and summarized in Table 3.

The bottom friction process was represented by the JONSWAP form with the friction coefficient of $0.038 \mathrm{~m}^{2} \mathrm{~s}^{-3}$ (Hasselmann et al. 1973). For the whitecapping process the adapted expression of Westhuysen et al. (2007) was used. The depthinduced wave breaking form of Battjes and Janssen (1978) and the non-linear triad interactions of Eldeberky and Battjes (1995) and Eldeberky (1996) were used with default values.

The sensitivity tests showed that an online coupling interval of 1-hour between the WAVE and FLOW modules were most adequate for the study area. The directional space was discretized into 72 directional bins, covering the full space $\left(360^{\circ}\right)$ and the frequency domain ranged from $0.05 \mathrm{~Hz}$ to $1 \mathrm{~Hz}$ with 24 bins (default). 
Table 3. Set of coefficients and parameters in SWAN used for the wind-wave modelling in Lagoa dos Patos, Brazil.
Physical Process
Formulation
Coefficients/
or Values
Wind growth
Koment et al. (1984)
Depth-induced wave breaking
Battjes and Janssen (1978)
$\alpha=1 ; \gamma=0.73$
Bottom friction
JONSWAP (Hasselman et al. 1973)
$0.038 \mathrm{~m}^{2} / \mathrm{s}^{-3}$

Non-linear triad wave-waveEldeberky and Battjes (1995) and $\alpha=0.1 ; \beta=2.2$.

interactions Eldeberky (1996)

Whitecapping Westhuysen (2007)

Refraction Activated

Water density

$1000 \mathrm{~kg} / \mathrm{m}^{3}$

Gravity

$9.81 \mathrm{~m} / \mathrm{s}$
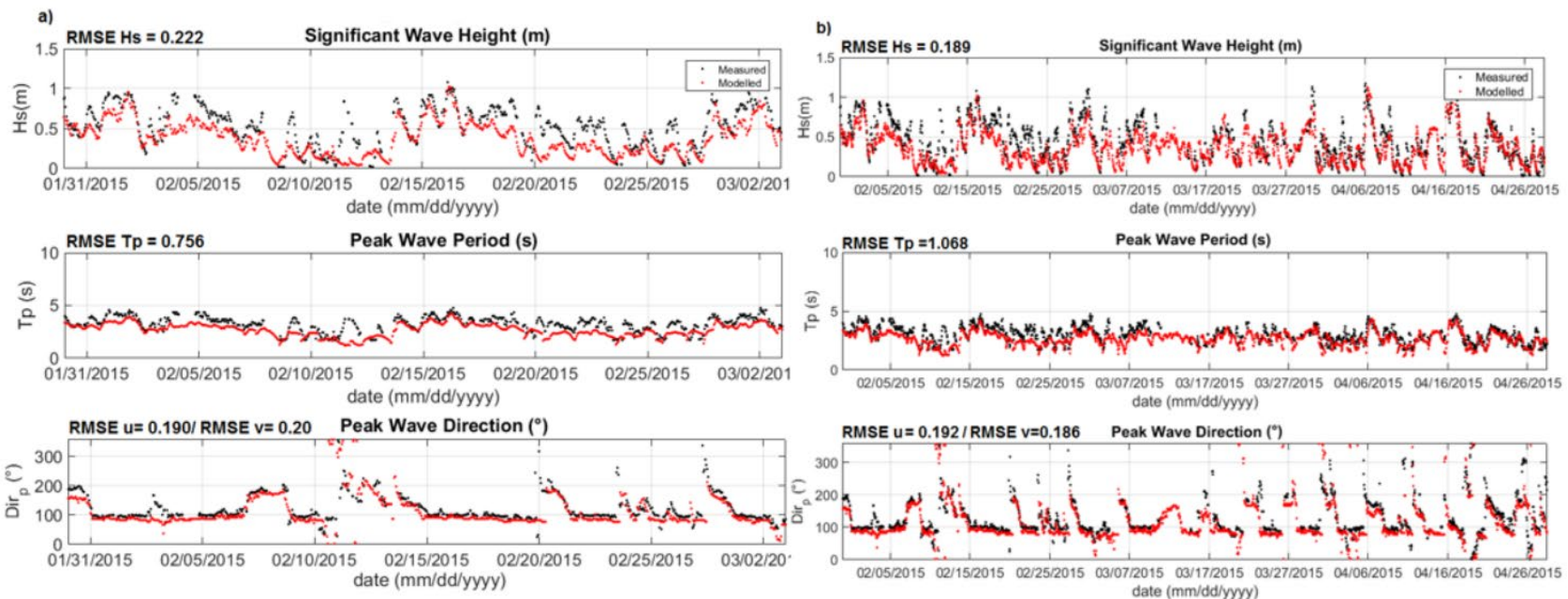

Figure 5. Model validation (Fig. 1 for buoy location). Left column: one month (top) and four months (bottom) of measured vs. modeled significant wave height (Hs) and peak period (Tp) and peak directon (Dir).

\section{Sensitivity Tests and Model Calibration}

Considering the numerical settings, the model run using the stationary computational mode (Run 01) showed the worst statistical performance parameters, with a RMSETp of $0.98 \mathrm{~s}$ of modelled peak wave period (Tp) in comparison to the $\mathrm{RMSE}_{\mathrm{Tp}}$ of $0.90 \mathrm{~s}$ for the run with the same settings (Run 3 ) in the non-stationary mode. No better results were obtained by using a shorter wave-flow coupling time interval and number of iterations, (120), in the stationary mode (Run 02) (Supplementary Material), 
while the computation in the non-stationary mode using shorter coupling time intervals, from $360 \mathrm{~min}$ (Run 03), to $180 \mathrm{~min}$ (Run 05), provided better model results with respect to the significant wave height and peak wave period (Supplementary Material).

Among the mechanisms of wave energy dissipation (bottom friction, depth-induced breaking and whitecapping), the highest influence on the modelled significant wave height was the whitecapping (when de-activated - Run 08), with an over-estimation of $60 \%$ of the significant wave height and a high root mean square error of $0.42 \mathrm{~m}$, whereas better results were found for the peak wave period $\left(\mathrm{RMSE}_{\mathrm{Tp}}=0.53 \mathrm{~s}\right)$ (Supplementary Material).

An improvement on the modelled peak wave period was found by using the Westhuysen et al. (2007) approach (RMSE $E_{\mathrm{Tp}}$ of 0.65s, Run 09), when comparing with the whitecapping formulation of Komen et al. (1984) (RMSETp=0.73 s, Run 07.2). Also, a minor under prediction of the modelled peak wave period was observed for the Westhuysen et al. (2007) formulation (16\%, Run 09) than Komen et al. (1984), 19\% (Run 07.2).

The empirical JONSWAP formulation of Hasselman et al. (1973) with the default bottom friction coefficient $\left(0.067 \mathrm{~m}^{2} \mathrm{~s}^{-3}\right)$ of Bouws and Komen (1983), showed slightly better model outputs $\left(\mathrm{RMSE}_{\mathrm{Hs}}=0.22 \mathrm{~m}, \mathrm{RMSE}_{\mathrm{Tp}}=0.87 \mathrm{~s}, \mathrm{RMSEV}_{\mathrm{V}}=0.20, \mathrm{RMSEU}_{\mathrm{U}}\right.$ $=0.20$ - Run 10) than the approach of Madsen et al. (1988), with the default coefficient of $0.05 \mathrm{~m}\left(\mathrm{RMSEHs}_{\mathrm{s}}=0.23 \mathrm{~m}, \mathrm{RMSE}_{\mathrm{Tp}}=0.91 \mathrm{~s}, \mathrm{RMSEv}=0.22, \mathrm{RMSEu}_{\mathrm{U}}=0.20-\mathrm{Run}\right.$ 11). Furthermore, the lower JONSWAP bottom friction coefficient of $0.038 \mathrm{~m}^{2} \mathrm{~s}^{-3}$ (Run 06) proposed for swell conditions by Hasselmann et al. (1973) provided better model results in Lagoa dos Patos than the high value of $\mathrm{C}_{\mathrm{b}}=0.067 \mathrm{~m}^{2} \mathrm{~s}^{-3}$ (Run 10) suggested for wind-driven seas by Bouws and Komen (1983) (Supplementary Material).

The modelled wave parameters did not show higher sensitivity with the deactivation of the non-linear triad wave-wave interaction process (Run 12-Run 05, deactivationactivation respectively). Other combinations were also tested and did not show a significant impact on the model results either.

Alongshore Wave Energy and Angles of Incidence.

The spits' morphodynamic evolution is intrinsically related to the incident wave field, more specifically; the angle of wave incidence $(\varphi-\theta)$ and the alongshore wave energy gradients. To investigate the action of these physical mechanisms on the considered coastline, incident modelled wave parameters in the vicinity of the depth of 
closure (3.3m) - calculated by the Hallermeier (1981) formula - were extracted from observation points along the coast. The angle of wave incidence was taken with respect to the wave direction $(\varphi)$ and the coastline orientation $(\theta)$ and the incident wave energy per unit of crest length (in $\mathrm{kW} / \mathrm{m}$ ) was calculated by the following equation:

$$
E=\frac{1}{2} H s^{2} T(k W / m)
$$

In which, $E$ is wave energy per unit of crest length $(\mathrm{kW} / \mathrm{m}), \mathrm{Hs}$ is the significant wave height, and $\mathrm{T}$ is the peak wave period.

\section{Wave Attenuation}

The wave attenuation ( $A t t)$ across the submerged spits' sandbars was estimated at 3 $m$ depth (depth of closure) in three longitudinal locations along each spit: 1) In the proximal region (closer to the subaerial spit), 2) At the central portion of the spit (middle) and, 3) At the distal portion (towards the central lagoon water body) (see Fig. 1 for location).

The measurements were made as a function of the significant wave height arriving (Hsi) and outgoing (Hst) from the northern and southern flanks of the spits, considering the waves from the first quadrant (NNE, NE, ENE) and vice-versa, considering the waves from the third quadrant (S-SSW and SW) by using the following simple equation:

$$
\mathrm{A} t t=1-\left(\frac{H s t}{H s i}\right) \times 100
$$

The wave fields propagating across the short lagoon axis (E, ESE, and SSE) were not included on the measurements of wave attenuation by the spits, due to the spits' orientation and the basin shape.

\section{Results}

This section is divided into two main topics; i.) The results of wave attenuation by the spits are first presented, followed by ii.) The alongshore variability of wave energy input along the nearshore region of the lagoon bay beaches [specifically, the incident wave energy $(\mathrm{W} / \mathrm{m})$ and associated angle of incidence to the shore $(\varphi-\theta)]$, considering different directions of wave generation.

Wave Attenuation over Lagoon Sandy Spits. 
A great variability of wave attenuation is observed along different portions of the spits, and it varies for different directions of wave generation, from $18 \%$ up to $46 \%$ (Fig. 6).

Maximum significant wave heights occur at the south of the first lagoon cell at a depth of $7 \mathrm{~m}$ (up to $0.96 \mathrm{~m}$ for the NE waves and 1.05 for the SSW waves). The wave direction closely follows the wind direction, until the waves refract over the submerged sandy spits. Energetic waves propagating across the long lagoon axis are attenuated and refracted by the analyzed cuspate spits towards the western lagoon bay beaches, except the SW waves which experience minimal refraction while crossing the submerged spits due to the nearly perpendicular wave-approach angles $\left(0.7^{\circ}-7.4^{\circ}\right)($ Supplementary material, Annex-D).

The NNE, NE and ENE waves are mainly attenuated at the proximal and central regions of the northern (Dona Helena) and central (Dona Maria) spits, in a rate of $39 \%$ to $46 \%$ of wave height attenuation, while less attenuation occurs at their distal portions (Fig. 6a). The distal portion of Dona Helena spit showed the smallest rates of wave attenuation for all wind-wave scenarios, with a minimum rate of $18 \%$ for the SW waves up to a maximum of $26 \%$ for the NE waves (Fig. 6a, see Fig. 1 for point location).

For the southern spit (Vitoriano), in turn, there is greater attenuation of the NNE, NE and ENE waves which occurs at its distal portion (Fig. 6c). NNE-ENE waves reach this sector with higher incident energy (amplitude) because these directions of wave generation have a larger fetch length and width, and also propagate through deeper waters (Table 4, Annex-D).

The S, SSW and SW waves, in contrast, are mainly attenuated on the proximal (41\% - 44\%) and central (33\% - 34\%) portions of Vitoriano spit (southern spit), and are less attenuated on the distal portion (27\% - $29 \%$ ) (Fig. 6c).

The waves generated by the S-SSW wind case approach the southern flank of the spits with the SSW and S directions. Higher degree of attenuation of S, SSW and SW waves occurs in the central $(40 \%-41 \%)$ and distal $(39 \%-40 \%)$ portion of Dona Maria spit and minor rates (but still representative) of attenuation occurs at the proximal region $(35 \%-37 \%)$.

Dona Helena spit (north), in turn, shows higher attenuation of S, SSW and SW waves in the proximal $(38 \%-42 \%)$ and central $(33 \%-36 \%)$ regions (Fig. 6a). 
After being transmitted by the spits, the waves do not reach the same size as they had before dissipating over the upwind spit. Even in regions with enough fetch for the reformation (the southern coast of the bay beaches for the NNE, NE and ENE waves, or, the northern coast of the bay beaches for the SW, SSW and S waves), mainly due to the reduced depths on the second and third lagoon cells.
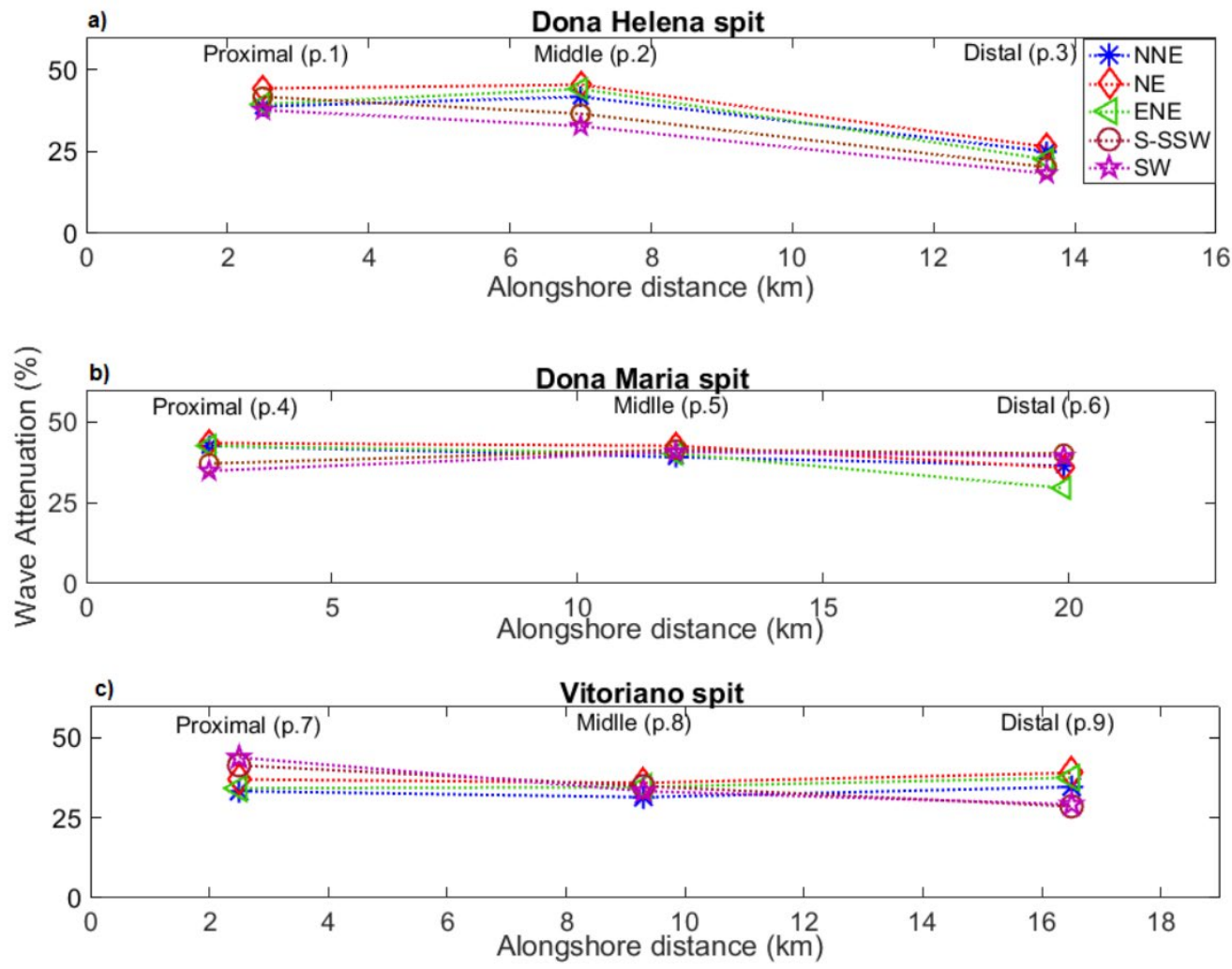

Figure 6. Wave attenuation (\%) along different portions of Lagoa dos Patos' sandy spits for waves generated by extreme wind cases blowing across the long lagoon axis, from the NNE, NE, ENE, S-SSW and SW directions. The control points used for the measurements of wave attenuation are demonstrated in figure 1 (p.1 to p.9). Dotted lines highlight the different degrees of wave attenuation along different portions of the spits for various wave directions. 
Table 4. Incident wave energy along different portions of the spits for wave fields from different directions.

\begin{tabular}{|c|c|c|c|c|c|c|}
\hline \multirow{2}{*}{\multicolumn{2}{|c|}{$\begin{array}{c}\text { Scenarios } \\
\text { Cuspate Spits }\end{array}$}} & NNE & $\mathrm{NE}$ & ENE & SW & S-SSW \\
\hline & & $(\mathrm{W} / \mathrm{m})$ & $(\mathrm{W} / \mathrm{m})$ & $(\mathrm{W} / \mathrm{m})$ & $(\mathrm{W} / \mathrm{m})$ & $(\mathrm{W} / \mathrm{m})$ \\
\hline \multirow{4}{*}{$\begin{array}{c}\text { Dona } \\
\text { Helena spit }\end{array}$} & p. 1 & 704.7 & 1061 & 985 & 545.1 & 1057.8 \\
\hline & n? & 10850 & 1433 & 1353 & 6035 & 11666 \\
\hline & p. 2 & 1085.9 & & 1353 & 095.5 & 1100.0 \\
\hline & p. 3 & 1126.4 & 1385 & 1266 & 811.6 & 1248.9 \\
\hline \multicolumn{2}{|c|}{$\begin{array}{l}\text { Dona Maria p.4 } \\
\text { spit }\end{array}$} & 953.4 & 1297 & 1183 & 601.3 & 1040.4 \\
\hline & p. 5 & 925.4 & 1183 & 1005 & 819.2 & 1180.1 \\
\hline & p. 6 & 917.2 & 1031 & 804 & 984.8 & 1358.6 \\
\hline \multirow{3}{*}{$\begin{array}{c}\text { Vitoriano } \\
\text { spit }\end{array}$} & p.7 & 664.3 & 867 & 956 & 879.3 & 1373.8 \\
\hline & p. 8 & 786.4 & 1034 & 1034 & 945.0 & 1335.0 \\
\hline & p.9 & 939.4 & 1170 & 1104 & 873.5 & 1028.7 \\
\hline
\end{tabular}

Alongshore distribution of the wave energy and incident wave angles $(\phi-\theta)$ on lagoon bay beaches.

The waves generated by the NNE, NE, and ENE winds show greater similarity on the alongshore distribution of the incident wave characteristics: typically the establishment of shadow zones on the northern coast of the beaches (sub-areas of local wave generation); an increase of incident wave energy towards the south; a very low occurrence of oblique wave incidence, which is restricted to the semi-protected sector of the coast (Fig. 7, point 3 of the NNB and point 12-14 of the SBB) and; smaller to virtually shore-normal wave-approach angles at the downdrift section of the beaches (Fig. 7a, b, and c, point 8 of the NBB and point 16 of the SBB).

On the northern bay beach, the incident alongshore energy distribution of waves generated by NNE, NE and ENE wind cases, increases towards the south, as follows: a) from $244 \mathrm{~W} / \mathrm{m}$ to $761 \mathrm{~W} / \mathrm{m}$ for the NNE case, b) from $368 \mathrm{~W} / \mathrm{m}$ up to $1008 \mathrm{~W} / \mathrm{m}$ for the $\mathrm{NE}$ case, and c) ENE - from $429 \mathrm{~W} / \mathrm{m}$ up to a maximum of $1002 \mathrm{~W} / \mathrm{m}$, decreasing to $979.0 \mathrm{~W} / \mathrm{m}$ at the extreme south.

The southern bay beach presents a similar pattern; however, it shows a larger shadow zone (and thus a larger sub-area of local wave generation), less alongshore incident wave energy intensity allied to lower energy gradients between the beach 
extremities, as follows; a) NNE - 270-499 W/m, from the north to south, b) NE - 349$719 \mathrm{~W} / \mathrm{m}$ and, c) ENE - 383-718 W/m (Fig. 7a, b, and c).

Thus, the northern coast of the lagoon bay beaches (leeward coast of the spits) is sheltered from the NNE, NE and ENE waves, while the southern sectors (the updrift coast of the spits) is exposed to higher incident wave energy with relatively small to virtually shore-normal approach-angles, as follows; $\varphi-\theta_{N N E}=16^{\circ}, \varphi-\theta_{N E}=7^{\circ}, \varphi-\theta_{E N E}=$ $0.5^{\circ}$ in the southern coast of the northern bay beach, and $\varphi-\theta_{N N E}=25^{\circ}, \varphi-\theta_{N E}=14^{\circ}, \varphi$ $\theta_{E N E}=5.0^{\circ}$ in the southern coast of the southern bay (Fig. 7a, b, and c).

The E wave scenario also resembles the NNE, NE and ENE wave scenarios. However, an overall high incident wave energy is observed on both bay beaches, with minor energy gradients between the beach extremities. It ranges from $543 \mathrm{~W} / \mathrm{m}$ to 799 $\mathrm{W} / \mathrm{m}$, from the north to the south coast of the northern bay beach (Arambaré), and from $451 \mathrm{~W} / \mathrm{m}$ to $822 \mathrm{~W} / \mathrm{m}$ - from the northern to the southern coast of the southern bay beach. The higher alongshore incident wave energy of this scenario is counteracted by smaller incident angles $\left(\varphi-\theta<10^{\circ}\right)$ on the central and south sector of the northern bay beach (Arambaré) and the southern sector of the southern bay beach (Fig. 7d).

There is a very low occurrence of oblique wave incidence on both bay beaches (less than 19\%) for wave fields from different directions (NNE, NE, ENE, E, S-SSW, and SW). On the Arambaré coastline (in the semi-protected sector of the northern bay beach, between observation points 2-3), the waves generated by the NNE, NE, ENE and E winds approach at oblique angles but with reduced energy because of the dissipation over Dona Helena spit. As opposed to the S-SSW wave field, whose oblique wave incidence is associated with an accentuated energy, due to the larger fetch length for the wave reformation after crossing Vitoriano spit. Though, this beach section is characterized by a shoreface with a wider and flatter slope.

On the southern bay beach, the oblique wave incidence occurs along the transitional morphological zone (with an accentuated narrowing) of the shoreface width (point 12 and point 14), mainly at point 14 . Point 12 marks the beginning of the morphological transition zone of the shoreface, where it presents wider width with a smoother slope, while point 14 marks the end of the morphological transition zone, which is characterized by a reduced intensity of the incident wave energy due to the enhanced wave refraction in this morphological transitional zone of the shoreface (ANNEX - C).

The clockwise rotation in the direction of wave generation, from the NNE to the E, increases the exposure of both analyzed beaches, and the susceptibility of the northern 
sector of the coast to the oblique wave-approach (Fig. 7a, b, c, and d). Likewise, the counter-clockwise rotation, from the SW to the SSE directions, increases the coastline exposure (Fig.7, f, g, and h). Both bay beaches present an accentuated degree of exposure to waves generated by the ESE winds, propagating through the transversal axis of the lagoon, and thus presenting high incident wave energy with quasihomogeneous alongshore distribution (Fig. 7e), due to the minor influence of the spits on this wave field.

Higher incident wave energy intensity (decreasing towards the south), is also observed for the SSE wave case on both bay beaches, allied to an increased occurrence of oblique wave-approach angles (Fig. 7f).

In regards to the S-SSW scenario, a decrease in the alongshore incident wave energy is also observed from the north to the south coast of Arambare $(889.8 \mathrm{~W} / \mathrm{m}-286 \mathrm{~W} / \mathrm{m})$ and from the north to the south of the southern bay beach (from $1104 \mathrm{~W} / \mathrm{m}$ to $254 \mathrm{~W} / \mathrm{m}$, respectively). The extreme south of the Arambaré coast (ENE facing orientation) is wave-sheltered, while transversal wave propagation is observed on the downcoast sector of the southern bay beach (E facing orientation) (Fig. 7g).

In the case of the SW waves, a very large wave shadow zone is observed along the central and south sectors of the northern bay beach and, along the south sector of the southern bay beach (Fig. 7h), while the northern coasts of Arambaré (S facing orientation with an accentuated curve to the SE) and the northern coast of the southern bay beach (generally SSE facing orientation) are exposed (Fig. 7h). 


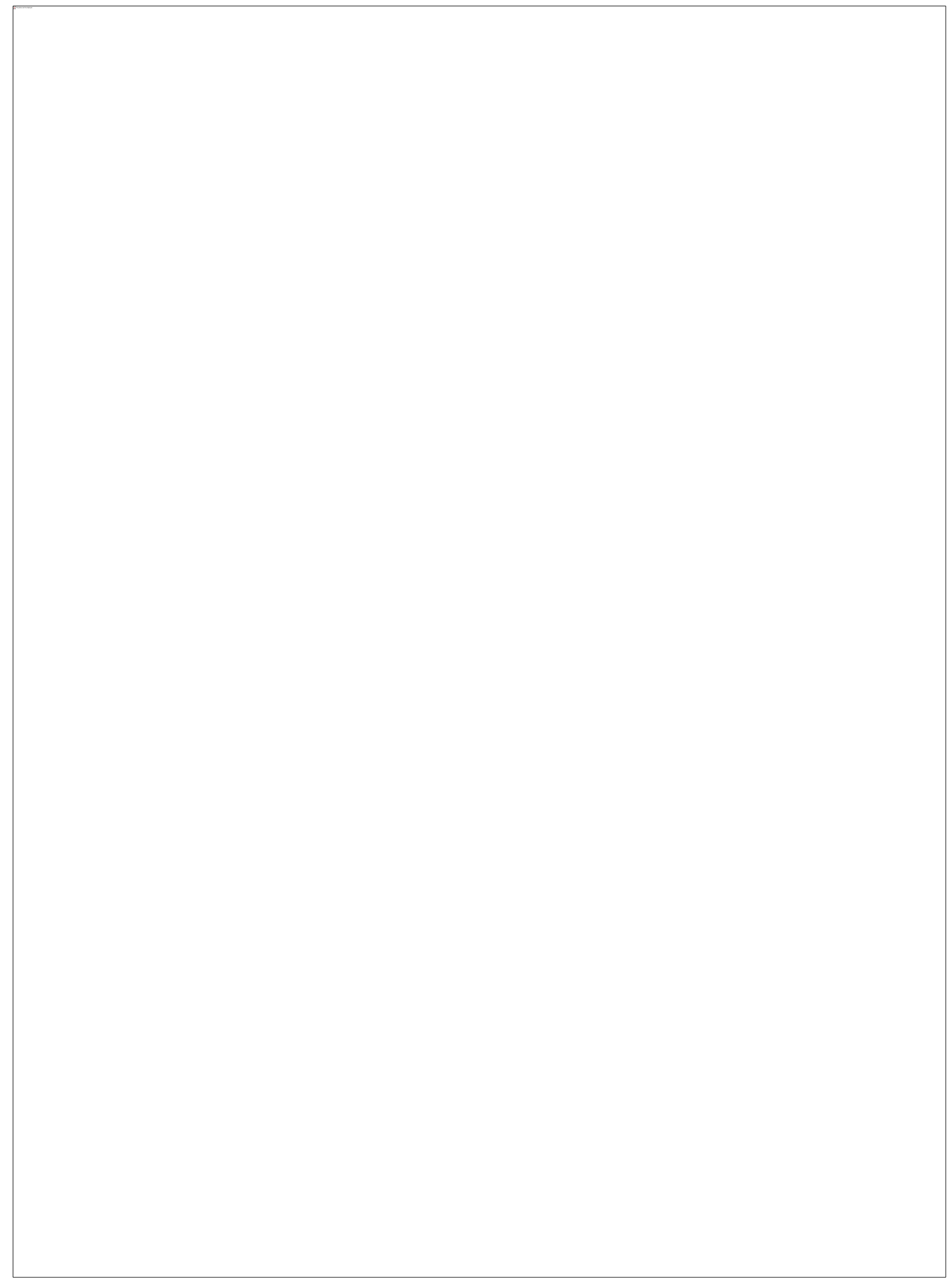

Figure 7. Alongshore distribution of the incident wave energy $(\mathrm{W} / \mathrm{m})$ per angle of wave-approach ( $\varphi-\theta$ triangles with dashed lines), including the wave shadow zones for the northern, Arambaré (from pto.1 to pto. 8) and southern bay beaches (from pto.9 to 
pto. 16) resultant of extreme wave field scenarios from various directions; from a) NNE, b) NE, c) ENE, d) E, e) ESE, f) SSE, g) S-SSW, to h) SW.

\section{Discussion.}

The wave attenuation by the lagoon sandy spits is discussed in the first section, in which the possible interactions of the wave dissipation mechanisms are assessed through the results of the sensitivity tests and comparisons with other wave attenuation studies. The second section concerns to the alongshore distribution of the wave energy and associated angles of incidence along the lagoon coastlines for representative wave field scenarios.

\section{Wave Attenuation.}

The depth-induced- and partial depth-induced wave breaking over the sandy spits seems to be the main wave dissipation mechanism in the lagoon (see Supplementary Material, Run 08). This finding is consistent with other studies in depth-limited wave growth situations (Westhuysen 2010; Xu et al. 2013), where the majority of the breaking events were associated with excessive wave steepness. For instance, Westhuysen (2010) has shown that SWAN normally underestimates the wave heights and periods on shallow flats due to the underestimation of dimensionless ratio $\mathrm{Hmo} / \mathrm{d}$ (significant wave height/local water depth) of the locally generated wind sea, thus proposing a new expression to resolve this model inaccuracy in finite depth environments.

The wave attenuation shows great variability along the spits (Fig.6), which can be associated to i) their variable morphology (a wider submerged shallow surface near to the root of the spits with an accentuated narrowing until its distal portions, ending up in deeper waters, see Fig. 1; Table 1), and to ii) the incident wave characteristics (amplitude), which depends on the direction of wave generation and the respective fetch length and width, and the water depth (Supplementary material, Annex-D).

The higher degree of attenuation of larger amplitude waves occurs at the distal portion of Vitoriano spit (NNE, NE and ENE waves) and at the distal portion of Dona Maria spit (S-SSW and SW waves) (Fig. 6), due to the larger fetch lengths and widths to those directions of wave generation, and because they propagate in deeper waters (Supplementary material, Annex-D). Similarly, Hardy et al. (1990) observed the influence of the wind regime and the fetch length and depth to variations in the wave 
height on the lagoon-reef system of the Great Barrier Reef, Australia, without follow up investigation.

Those results corroborates and complements Toldo et al. (2006a) study who observed that for a certain location of the lagoon coastline and wind condition, the incident wave characteristics (Hs and Tp) are defined by the fetch and depth, thus demonstrating the limiting effect of the lagoon basin shape in the wave growth. Those authors also emphasized the establishment of sub-areas of local wave generation (by the surrounding landforms - the spits) which assumes greater importance in the final stages of cuspate shorelines development. As the larger the wave shadow zone (and larger dimension of the cuspate feature), the larger the influence of the sub-area of local wave generation (ex.: leeward side of Dona Maria spit).

In embayed beaches on the ocean shore, Vieira da Silva et al. (2018) showed the dependence of the coastline orientation (in association with the local bathymetry) on alongshore variations in the wave attenuation process, with respect to the incoming wave direction. Those authors also highlight the importance of wave refraction on the alongshore variability of wave attenuation on non-straight coastlines. In the Lagoa dos Patos cuspate coast case, a similar alongshore variation in the wave attenuation is observed depending on the direction of wave generation, and the coastline exposure (Fig. 7). Although refraction effects are very limited in the nearshore region of the lagoon bay beaches (due to the narrow shoreface and the short-crested generated waves), the wave refraction over the submerged spits has a significant influence on the degree of exposure of the adjacent coastline.

Moreover, the enhanced wave refraction on the morphological transition zone of the shoreface promotes a slight reduction of the incident energy on the downdrift coast of the bay beaches (the updrift coast of the spits), a process more evidenced on the southern bay beach.

The NE, ENE and E waves generated by the predominant winds (Table 1) are mainly attenuated while crossing the proximal and central region of the northern (Dona Helena) and central (Dona Maria) spits, with a rate of 39\% to $46 \%$ respectively (Fig. 6). The reduction of transmitted energy to the adjacent coastline at the leeward side of the spits (Fig. 7) demonstrates the control of the wave attenuation in the stability of the adjacent coast. This is in agreement with the study performed by Miranda et al. (2019), which observed a prevailing stability trend on the medium-term analysis of the 
shoreline change (1984-2013), with a slight progradation trend along the northern coast of the bay beaches (leeward side of the spits).

This stable behavior of the coastline (Miranda et al. 2019) can be associated with the cuspate spits' influence on waves through the wave attenuation process and the wave sheltering provided by the spit.

Therefore, the lagoon sandy spits, similarly to a submerged breakwater (Jackson et al. 2010) and a barrier reef (Hegge et al. 1996; Lowe et al. 2005), act as natural protection of the coast by reducing the transmitted energy to the adjacent bay beaches on the leeward side of the spits, especially during episodic storm wind events acting over the longer lagoon axis (NNE, NE, ENE, S-SSW and SW). Moreover, even the waves that pass over a submerged breakwater without breaking are reduced in energy (Jackson et al. 2010) as are the waves that pass over the submerged cuspate spits during lagoon wave fields of moderate energy (not shown here).

Thus, allied to the wave sheltering effect promoted by the presence of the emerged cuspate features (Ells and Murray, 2013), the wave transformation processes (especially attenuation and refraction) over the submerged spits are also an important control on the stability of the adjacent coastlines.

Nonetheless, the wave attenuation over the shallow submerged crest of the spits is also responsible for its progressive erosion. Wave-induced sedimentary reworking first evidenced by Toldo (1991) through sediment and bathymetric profile analysis and confirmed by Miranda et al. (2019) which observed the cannibalization process of the spits due to the reduced sediment supply, as the erosion of the adjacent beaches are their main sources of sediments.

Moreover, this continued natural wave-induced erosion of the submerged spits can lead to a decrease in the effectiveness of the wave attenuation into the lagoon, which in a future scenario (from decades to centuries) can lead to an increase in the movement of the lagoon shorelines.

Alongshore Distribution of Wave-Approach Angles $(\varphi-\vartheta)$ and Energy $(\mathrm{W} / \mathrm{m})$ on a Cuspate Shoreline.

The alongshore distribution of wave energy and incident directions of predominant waves are important controls on the spatial variability of morphological changes in wave-dominated coasts, especially on the morphology of spits which are highly controlled by the incident wave characteristics and the sediment supply (Zenkovitch 
1959; Rosen 1979; Ashton et al. 2001; Allard et al. 2008; Petersen 2008; Lopez-Ruiz et al. 2012; Murray and Ashton 2013; Escudeiro et al. 2019).

For fetch-limited water bodies, the high proportion of oblique wave-approach angles generated by winds blowing across the long fetch is the primary forcing control on the evolution of shoreline features in a cuspate form (Zenkovitch 1959; Rosen 1979; Ashton et al. 2009). On Lagoa dos Patos, a very low occurrence (less than 19\%) of oblique wave incidence, between $30^{\circ}$ to $60^{\circ}$, is observed along the coast for different wave field directions, especially for those propagating across the long lagoon axis (Fig. 7). This is attributed to the influence of the cuspate spits themselves on the lagoon wave climate.

The influence of the cuspate spits on the lagoon wave climate in their final stages of development ( half of the lagoon width) was first highlighted by Zenkovitch (1959), who reported that the spits act as obstacles to the free wave propagation across the long lagoon axis, by impeding them to maintain their former size, and thus reducing their influence on the coast and dissipating the tendency towards asymmetry. After that, the analytical Coastline Evolution Model (CEM) developed by Ashton et al. (2009) to represent the large-scale evolution of cuspate features in an elongated lagoon water body showed that the growth of cuspate features changes the local wave fields, leading to a reduced local proportion of high-angle waves despite the regional instability. This behavior was observed in the modeled features of CEM, and in the natural cuspate features of the North Carolina Coast (EUA) (Ashton and Murray 2006b) and now in Lagoa dos Patos, as it can be seen by the incident wave angles in the nearshore region of the lagoon bay beaches (Fig. 7) and the directional wave roses in the center of each lagoon cell (Fig. 1) with the resultant waves oriented at oblique angles to the shore.

The results achieved here are in accordance with Ashton et al.'s (2009) observations, notwithstanding that for this study it seemed more reasonable to use the wave parameters at the depth of closure instead of at "deeper waters" (before refraction and shoaling), as refraction is virtually absent on the analyzed bay beaches and the submerged spits exert an important influence on the wave propagation patterns due to their due to their shallow crest depth $(\sim 1 \mathrm{~m})$ and wider width (Table 1, Supplementary Material, Annex-D).

The direction of wave generation and the wave transformation processes over the submerged spits (mainly refraction and the dissipation mechanisms) in association with the lagoon coastline configuration (orientation) demonstrate important controls on the 
alongshore distribution of the wave energy $(\mathrm{W} / \mathrm{m})$ and incident angles $(\varphi-\theta)$. Such that similar patterns of local wave angles and energy occur along the lagoon bay beaches coastline for wave fields from different directions (Fig. 7).

An increase in the wave sheltered coastal area is observed for the wave fields propagating across the long lagoon axis, which are coincident with the bimodal wind regime - dominant NE winds throughout the year and prevailing SW and southerly winds during autumn and winter (Delaney 1965; Stech and Lorenzetti 1992; Tomazelli 1993; Klein 2012). The degree of sheltered coast is related to the larger projection (dimension) and orientation of the emerged spit. The larger the subaerial spit, the greater is the extension of the wave sheltered coastal area for wave fields propagating across the long lagoon axis. This can be seen by the larger projection of the emerged Dona Maria spit and the larger extension of sheltered coast of the southern bay beach to the NNE, NE and ENE waves. Likewise, there is significant sheltering of the Arambaré coast (northern bay beach) from the SW waves (Fig. 7).

The wave refraction over the spit's sandbars also demonstrates an influence on the degree of shadowing. Reduced refraction is observed when a better alignment of the cuspate feature to the incident wave direction occurs, which also results in a larger wave shadow zone (eg.: southern coast of Arambaré to the SW waves, and northern coast of the southern bay to the NNE, NE and ENE scenarios) (Supplementary material, Annex D).

Despite the similar pattern in the alongshore distribution of the incident wave characteristics at a regional level (Fig. 7), the degree of exposure differs between the two analyzed bay beaches to waves under the same wind condition. Similar behavior was observed on estuarine beaches in New Jersey (USA) by Jackson and Nordstrom $(1992,92)$ who stated that "processes that are similar at regional level express themselves differently at local level because of site specific controls". For the authors' case, the shoreline orientation affects the degree to which refracted ocean waves alter the incident wave field. In this case, the projection (dimension/amplitude) of the emerged cuspate spits and its submerged morphology controls the extension of shadowed area and how the waves are modified (attenuated and refracted) by the spits exerts an important control on variations in the incident wave characteristics along the lagoon shores.

The low occurrence of oblique wave incidence (less than 19\%) from waves generated by winds blowing across the long lagoon axis is attributed to the advanced 
stage of development of the analyzed cuspate features, in which the coastline tends to be reoriented in accordance to the predominant wave directions in a cuspate-like shape.

The shoreline reorientation process is known to be driven by strong gradients in the alongshore sediment transport due to the high proportion of oblique wave angles to the shore (Zenkovitch 1959; Rosen 1979; Ashton et al. 2001; Ashton and Murray, 2006a, 2006b). In this case, not only is there a limited occurrence of oblique wave angles of incidence, but the restricted oblique incidence of the predominant waves has reduced energy due to the dissipation by the spits.

The waves propagating across the main lagoon axis are assumed to be the main drivers of morphological changes into elongated lagoons (Zenkovitch, 1959; Rosen 1979; Toldo et al. 2003; Ashton et al. 2009). In the Lagoa dos Patos case, it is observed that a strong relationship of mutual co-adjustment exists between the morphology and the hydrodynamics (specifically the incident wave characteristics) in a manner to confer a reduced proportion of oblique wave incidence and high effectiveness of the wave attenuation process along the lagoon margins, especially for the wave fields generated by the winds blowing across the long lagoon axis.

Whereas, the wave fields generated across the short lagoon axis assume greater importance in the morphological response on this stage of the lagoon development. This is attributed to the minor influence of the lagoon cuspate spits in these wave fields (by the wave-sheltering and attenuation). Result which agrees with the first observations of Zenkovitch (1959), who stated the increased role of waves generated across the short lagoon axis on the final stages of the water body development. A consequence of the increased curvature radius of updrift beaches with the lateral growing of the paired cuspate spits, causing increased fetch lengths with the augment of the lagoon cells width (Zenkovitch, 1959, modified).

\section{Conclusion}

This work investigates the wave attenuation and alongshore variability of wave energy input [specifically the energy $(\mathrm{W} / \mathrm{m})$ and angle of incidence to the shore $(\varphi-\theta)$ ] along the nearshore region of a lagoon cuspate shoreline in the west coast of Lagoa dos Patos by using a process-based model (Delft3D) validated with measured wave data.

The large-scale sandy spits on the landward margin of Lagoa dos Patos are shown to be responsible for the attenuation of waves generated during representative energetic wind conditions over the lagoon water body (by up to 46\%). Furthermore, wave 
dissipation varies along different portions of the spits (i. Proximal, closer to the root; ii. Central, and iii. At the distal end), from $18 \%$ to $46 \%$, depending on each spit's morphology and the incident wave properties (which are closely related to the direction of wave generation and the respective fetch length and width, and the water depth). Therefore, the fetch (the lagoon coastline configuration) and the bathymetry (the submerged morphology) controls the wave attenuation along the lagoon coastlines.

Elucidations of the influence of cuspate spits of Lagoa dos Patos with respect to the degree of exposure of the lagoon beaches were also demonstrated. The cuspate features influence the lagoon wave climate and consequently the energy input entering the nearshore region of the bay beaches by the wave sheltering effect, acting as obstacles to the free wave propagation, and by the wave transformation processes over the submerged spits, mainly through the dissipation mechanisms (attenuation) and refraction.

Therefore, the wave attenuation over the spits is an important control on the stability of the adjacent coastline due its buffering effect during high wave energy events within the lagoon. This process is also responsible for its progressive erosion, and in a future scenario (from decades to centuries), it is expected to have implications for the stability of these lagoon bay beaches in terms of increasing shoreline changes.

The results presented here characterized the wave forcing condition entering the nearshore region of the rhythmic coastline of a mature elongated lagoon (Lagoa dos Patos, Brazil), in which alongshore wave energy gradients are observed along the cuspate coast. However, there is a limited occurrence of oblique wave incidence (less than 19\%), for wave fields from different directions (NNE, NE, ENE, E, S-SSW, and SW), especially for the predominant NE and ENE waves, for which oblique wave incidence is restricted to the semi-protected sector of the beach (beach section with a wider and gentle sloping shoreface), and for dominant SW waves (associated with the passage of cold fronts) which presents a larger wave shadow zone.

Ultimately, this type of study can also be translated to other study areas (eg.: estuarine beaches and embayed beaches on the ocean shore) and can also inform studies of coastal protection measured with low crested and submerged structures, such as detached breakwaters and artificial reefs.

References 
Allard J, Bertin X, Chaumillon E, Pouget F (2008) Sand spit rhythmic development: A potential record of wave climate variations? Arçay Spit, western coast of France. Marine Geology 253: 107-131. https://doi.org/10.1016/j.margeo.2008.05.009.

Andrade Neto JS, Rigon LT, Toldo EE, Jr, Schetinni F (2012) Descarga sólida em suspensão do sistema fluvial do Guaíba, RS, e sua variabilidade temporal. Pesquisas em Geociências 39(2): 161-171.

Aronow S (1982) Lakes, coastal morphology. In: Beaches and Coastal Geology. Encyclopedia of Earth Science. Springer, Boston, MA.

Ashton A, Murray AB, Arnault O (2001) Formation of coastline features by larga-scale instabilities induced by high-angle waves. Nature 414(6861): 296-300. https://doi.org/10.1038/415666a.

Ashton AD, Murray AB (2006a) High-angle wave instability and emergent shoreline shapes: 1. Modeling of sand waves, flying spits, and capes. Journal of Geophysical Research 111(F04011): 1-19. http://dx.doi.org/10.1029/2005JF000422.

Ashton AD, Murray AB (2006b) High-angle wave instability and emergent shoreline chapes: 2. Wave climate analysis and comparisons to nature. Journal of Geophysical Research 111(F04012): 1-17. https://doi.org/10.1029/2005JF000423.

Ashton, AD, Murray AB, Littlewood R, Lewis DA, Hong P (2009) Fetch-limited selforganization of elongated water bodies. Geology 37(2): 18-190.

Battjes JA, Janssen JPFM (1978). Energy loss and set-up due to breaking of rambom waves. In: Proceedings of 16th Conference on Coastal Engineering, Hamburg, Germany, pp 569-587.

Benedet L, Dobrochinski JPF, Walstra DJR, Klein AHF, Ranasingle R (2016) Coastal Engineering, 112: 69-86. http://dx.doi.org/10.1016/j.coastaleng.2016.02.005.

Booij N, Ris RC, Holthuijen LH (1999) A third-generation wave model for coastal regions, 1. Model description and validation. Journal of Geophysical Research 104(C4): 7649-7666. https://doi.org/10.1029/98JC02622.

Bouws E, Komen GJ (1983) On the balance between growth and dissipation in an extreme, depth-limited wind-sea in the southern North Sea. J. Phys. Oceanogr 13: $1653-1658$.

Carter RWG (1988) Tidal and Lake Coasts. In: Carter, R.W.G. (Eds.) Coastal Environments; an introduction to the physical, ecological and cultural systems of coastlines, ${ }^{\circ} 1$ st.ed. San Diego, CA 92101: Academic Press Inc., 1988. cap. $n^{\circ} 4$, p.151-198.

Carter RWG, Woodrofe CD (1994) Coastal Evolution: Late Quaternary shoreline morphodynamics. Cambridge: Cambridge University Press, 517p. 
Cowell PJ, Thom BG (1994) Morphodynamics of coastal evolution, In: Carter RWG, Woodroffe CD(Eds.) Coastal Evolution. Crambridge University Press, United Kingdom, pp 33-86.

Delaney PJV (1965) Fisiografia e Geologia de Superfície da Planície Costeira do Rio Grande do Sul. Publicação Especial da Escola de Geologia (6). Porto Alegre, UFRGS, 105p.

Eldeberky Y, Battjes JA (1995) Parameterization of triad interactions in wave energy models, Proceedings of Coastal Dynamics '95, 140-149.

Eldeberky Y. (1996). Nonlinear transformations of wave spectra in the nearshore zone, Ph.D Thesis, Fac. of Civil Engineering, Delft University of Technology, 203 pp.

Ells K, Murray AB (2012) Long-term, non-local coastline responses to local shoreline stabilization. Geophysical Research Letters, 39: L19401, 1-7. https://doi.org/10.1029/2012GL052627.

Escudero M, Silva R, Hesp PA, Mendoza E (2019) Morphological evolution of the sandspit at Tortugueros beach, Mexico. Marine Geology 407: 16-31. https://doi.org/10.1016/j.margeo.2018.10.002.

Fernandes EHL, Mariño-Tapia I, Dyer KR, Moller OO, 2004. The attenuation of tidal and subtidal oscillations in the Patos Lagoon estuary. Ocean Dynamics 54 (3-4): 348-359. https://doi.org/10.1007/s10236-004-0090-y.

FitzGerald DM, Buynevich IV (2009) Coastal Barriers. In: Isla FI, Iribarne O (Eds.), Coastal zones and estuaries. UNESCO - Encyclopedia of Life Support Systems, United Kingdom, pp 164-189.

French J, Payo A, Muray B, Orford J, Eliot M, Cowell P (2016) Appropriate complexity for the prediction of coastal and estuarine geomorphic behavior at decadal to centennial scales. Geomorphology 256, 3-16.

Hallermeier RJ (1981) A profile zonation for seasonal sand beaches from wave climate. Coastal Engineering 4: 253-277. https://doi.org/10.1016/0378-3839(80)90022-8.

Hardy TA, Young IR, Nelson RC, Goulay MR (1990) Wave attenuation on an offshore coral reef. In: Proceedings of the $22^{\text {nd }}$ International Conference on Coastal Engineering, Delft, Netherlands, pp 330-344. https://doi.org/10.1061/9780872627765.027.

Hasselman K, Barnett TP, Bouws E, et al (1973) Measurements of win-wave growth and swell decay during the Joint North Sea Wave Project (JONSWAP). Deutsches Hydrographisches Institut, Hamburg, 12 (A8): 1-95.

Hegge B, Elliot I, Hsu J (1996) Sheltered sandy beaches of southwestern Australia. Journal of Coastal Research 12 (3): 748-760. 
Héquette A, Ruz MH (1991) Spit and barrier island migration in the southeasthern Canadian Beaufourt Sea. Journal of Coastal Research 7(3): 677-698.

https://www.jstor.org/stable/4297885.

Jackson NL, Nordstom KF (1992) Site specific controls on wind and wave processes and beach mobility on estuarine beaches in New Jersey, U.S.A. Journal of Coastal Research, 8(1): 88-98.

Jackson LA, Corbett B, Salyer A, Mocke G, Smit F, Strauss D, Tomlinson R (2010) Low crested reef breakwaters - Theory illustrated by Arabian Gulf Projects. In: Proceedings of the 2nd International Conference on Coastal Zone Engineering and Management (Arabian Coast 2010). Muscat, Oman, UAE.

Klein AHF (2012) Regional Climate. In: Seeliger U, Odebrecht C, Castello JP (Eds.). Subtropical Convergence Environments: The Coast and Sea in the Southwestern. Springer-Verlag, Heidelberg, Germany, pp. 5-7.

Komen GJ, Hasselmann S, Hasselman K (1984) On the existence of a fully-developed wind-sea spectrum. Journal of Physical Oceanography 14: 1271-1285. https://doi.org/10.1175/1520-0485(1984)014<1271:OTEOAF>2.0.CO;2.

Lesser, GR, Roelvink, JA, van Kester, JATM, Stelling GS (2004) Development and validation of a three-dimentional morphological model. Coastal engineering, 51 (8): 883-915. https://doi.org/10.1016/j.coastaleng.2004.07.014.

Lin W, Sanford LP, Suttles SE (2002) Wave measurement and modeling in Chesapeake Bay. Continental Shelf Research 22: 2673-2686. https://doi.org/10.1016/S02784343(02)00120-6.

López-Ruiz A, Ortega-Sánchez M, Baquerizo A, Navidad D, Losada MA, 2012. Nonuniform alongshore sediment transport induced by coastline curvature. Coastal Engineering Proceedings 33: 1-10. https://doi.org/10.9753/icce.v33.sediment.29.

López-Ruiz A, Ortega-Sánches M, Baquerizo A, Losada MA (2014) A note on alongshore sediment transport on weakly curvilinear coasts and its implcations. Coast. Eng. 88, 143-153. https://doi.org/10.1016/j.geomorph.2012.03.001.

López-Ruiz A, Solari S, Ortega-Sánches M, Losada MA (2015) A simple approximation for wave refraction - Application to the assessment of the nearshore wave directionality. Ocean Modelling, 96, 324-33.

http://dx.doi.org/10.1016/j.ocemod.2015.09.007.

Lowe RJ, Falter JL, Bandet MD, Pawlack G, Atkinson MJ, Monismith SG, Koseff JR (2005) Spectral wave dissipation over a barrier reef. Journal of Geophysical Research, 110 (C04001): 1-16. https://doi.org/10.1029/2004JC002711.

Madsen OS, Poon YK, Grabe, HC (1988) Spectral wave attenuation by bottom friction: Theory. In: Procedings of 21th International Conference on Coastal Engineering, American Society of Civil Engineering, New York, pp 492-

504. https://doi.org/10.9753/icce.v21.\%25p. 
Miranda IM, Toldo EE, Jr, Klein AHF, Vieira da Silva, G (2019) Shoreline evolution of lagoon sandy spits and adjacent beaches, Lagoa dos Patos, Brazil. Journal of Coastal Research, 35(5), 1010-1023. Coconut Creek (Florida), ISSN 0749-0208.

Moller OO, Lorenzzentti JA, Stech JL, Mata MM (1996) The Patos Lagoon summertime circulation and dynamics. Continental Shelf Research, 16(3), 335-351. doi: 10.1016/0278-4343(95)00014-R.

Murray AB, Ashton AD (2013) Instability and finite-amplitude self-organization of large-scale coastline shapes. Philosophical Transactions of The Royal Society A, 371: 1-15. http://dx.doi.org/10.1098/rsta.2012.0363.

Nicholls RJ, Townend IH, Bradbury, AP Ramsbottom D, Day SA (2013) Planning for long-term coastal change: experience from England and Wales. Ocean Eng. 71, pp.3-16.

Nobre CA, Cavalcanti MAG, Nobre P, Kayano MT, Rao VB, Bonatti JP, Satyamurti P, Uvo CB, Cohen JC (1986) Aspectos da climatologia dinâmica do Brasil. Climanálise número especial.

Nordstrom KF (2005) Bay Beaches. In: Schwartz, M. (Eds.) Encyclopedia of Earth Sciences Series, Springer, Netherlands, pp 129-130.

Park JV, Wells JT (2007) Spit growth and downdrift erosion: results of longshore transport modelling and morphologic analysis at the Cape Lookout cuspate foreland. Journal of Coastal Research 23(3): 553-568. https://doi.org/10.2112/03-0116.1.

Petersen D, Deigaard R, Fredsoe J (2008). Modelling the morphology of sandy spits. Coastal Engineering, 55: 171-184.

Ris RC, Holthuijsen LH, Booji N (1999) A Third-generation wave model for coastal regions, 2.Verification. Journal of Geophysical Research 104(C4): 7667-7681. https://doi.org/10.1029/1998JC900123.

Roelvink JA, (2006) Coastal morphodynamic evolution techniques. Coastal Engineering, 53 (2): 277-287. https://doi.org/10.1016/j.coastaleng.2005.10.015.

Rosen PS (1975) Origin and progress of cuspate spit shorelines. In: Cronin, L.E. (ed), Estuarine Research, Vol. II. Academic press, New York, SFO, pp. 77-92. https://doi.org/10.13140/2.1.3070.7208.

Saraiva JMB, Bedran C, Carneiro C (2003) Monitoring storm surges on Cassino Beach, RS, Brazil. In: Klein AHF, Finkl CW, Rorig LR, Santana GG, Diehl FL, Calliari LJ (eds.), Proceedings of the Brazilian Symposium on Sandy Beaches:

Morphodynamics, Ecology, Uses, Hazards and Management. Journal of Coastal Research, Special Issue No. 35, pp. 323-331.

Schossler V, Simões JC, Aquino FE, Viana DR (2018) Precipitation anomalies in the Brazilian southern coast related to the SAM and ENSO climate variability modes. Brazilian Journal of Water Resources, 23(14), 1-10. 
Stech JL, Lorenzzeti JA (1992) The response of the south Brazil bight to the passage of wintertime cold fronts. Journal of Geophysical Research 97(C6): 9507-9520. https://doi.org/10.1029/92JC00486.

Thornton ED, Dalrymple, T, Drake T, Elgar S, Gallagher E, Guza B, Hay A, Holman R, Kaihatu J, Lippman T, Ozkan-Haller T (1998) Nearshore Processes Research. Report Based on the Nearshore Research Workshop. St. Petersburg, Florida, September 14-16.

Toldo EE, Jr, (1991) Morfodinâmica da Laguna dos Patos, Rio Grande do Sul. Pesquisas em Geociências 18(1): 58-63. https://doi.org/10.22456/1807-9806.21362.

Toldo EE, Jr, Almeida LESB, Côrrea ICS (2003) Forecasting shoreline changes of Lagoa dos Patos Lagoon, Brazil. Journal of Coastal Research 19: 43-50. https://www.jstor.org/stable/40928747.

Toldo EE, Jr, Almeida LESB, Corrêa ICS, Ferreira ER, Gruber NLS (2006a) Wave prediction along Lagoa dos Patos coastline, southern Brazil. Atlântica 28 (2): 87-95.

Toldo EE, Jr., Dillenburg SR, Côrrea ICS, Almeida LESB, Weschenfelder J, Gruber NLS (2006b) Sedimentação de longo e curto período na Lagoa dos Patos, Sul do Brasil. Pesquisas em Geociências 33(2): 79-86. https://doi.org/10.22456/18079806.19516.

Tomazelli LJ (1993) O Regime de Ventos e a Taxa de Migração das Dunas Eólicas Costeiras do Rio Grande do Sul, Brasil. Pesquisas em Geociências 20(1): 18-26. https://doi.org/10.22456/1807-9806.21278.

Tomazelli, LJ Dillenburg SR Villwock JA (2000) Late Quaternary History of Rio Grande do Sul Coastal Plain, Southern Brazil. Revista Brasileira de Geociências, v. 30, n. 3, p. 470-472.

Vaz AC, Moller AA, Almeida TL (2006) Análise quantitativa da descarga dos rios afluentes da Lagoa dos Patos. Atlântica (Rio Grande), 28(1), 13-23.

Vieira da Silva G, Murray T, Strauss D (2018) Longshore wave variability along nonstraight coastlines. Estuarine, Coastal and Shelf Science 212(15): 318-328. https://doi.org/10.1016/j.ecss.2018.07.022.

Villwock JA (1984). Geology of the coastal province of Rio Grande do Sul, southern Brazil. A Synthesis. Pesquisas em Geociências 16(16): 5-49.

Xu F, Perrie W, Solomon S (2013) Shallow water dissipation processes for wind waves off the Mackenzie Delta. Journal Atmosphere-Ocean 51 (3): 296-308. https://doi.org/10.1080/07055900.2013.794123.

Westhuysen AJ, Van der, Zijlema M, Battjes JA (2007) Nonlinear saturation-based whitecapping dissipation in SWAN for deep and shallow water. Coastal Engineering, 54: 151-170. https://doi.org/10.1016/j.coastaleng.2006.08.006. 
Westhuysen AJ (2010). Modeling of depth-induced wave breaking under finite-depth wave growth conditions.Journal of Geophysical Research, 115(C01008): 1-19. https://doi.org/10.1029/2009JC005433.

Zenkovitch VP (1959) On the genesis of the cuspate spits along lagoon shores. The Journal of Geology 67(3): 269-277. 